\title{
Relationship between Clusterin Gene Expression and In-vitro Sperm Characteristics in Caprine Semen
}

\author{
M. Vengatachalam ${ }^{1 *}, K$. Loganathasamy ${ }^{2}$, V. Leela ${ }^{3}$ and J. Ramesh ${ }^{4}$ \\ ${ }^{1}$ Veterinary Dispensary, Thenkarai, Sivagangai, Tamil Nadu, INDIA \\ ${ }^{2}$ Department of Veterinary Physiology and Biochemistry, Veterinary College and Research Institute, Ramayanpatti, Tirunelveli, \\ Tamil Nadu, INDIA \\ ${ }^{3}$ Department of Veterinary Physiology, Madras Veterinary College, Vepery, Chennai, Tamil Nadu, INDIA \\ ${ }^{4}$ Department of Animal Nutrition, Madras Veterinary College, Vepery, Chennai, Tamil Nadu, INDIA
}

*Corresponding author: KLoganathasamy; E-mail: Insamy75@gmail.com

Received: 22 Aug., 2019

Revised: 14 Oct., 2019

Accepted: 28 Oct., 2019

\begin{abstract}
The present experiment was undertaken to study the relationship between clusterin (CLU) gene expression and in vitro sperm characteristics in buck semen. Fresh semen samples were collected from 12 bucks maintained in the organized goat farms by artificial vagina. Normalization of initial concentration of spermatozoa was carried out in all buck semen samples before proceeding for RNA isolation. So, initial concentration of each sample was made equal. The spermatozoa were isolated from buck semen samples by swim- up protocol using sperm TALP. Total RNA from the buck spermatozoa were extracted and first strand cDNA was synthesized from $1 \mu \mathrm{g}$ total RNA by using commercial kits. Absolute quantification of CLU gene transcripts in semen samples from 12 bulls was performed by plotting standard curve. Variations in levels of CLU gene transcripts (250022546000 copies) were found among 12 different buck semen samples. In vitro sperm characteristics were also studied from 12 buck semen samples. Variations in sperm characteristics such as sperm motility $(60.0-80.0 \%)$, sperm viability $(72.0-93.0 \%)$, sperm morphology (73.0 - 91.0\%), plasma membrane integrity $(50.0-82.0 \%)$, acrosome integrity $(81.0-93.0 \%)$, DNA integrity (82.0 - 93.0\%) and MMP (46.0 - 74.0\%) were found among buck semen samples. All in vitro sperm characteristics were highly (negatively) correlated $(\mathrm{p}<0.01)$ with expression levels of CLU gene transcripts in spermatozoa. From this study, it is evident that ejaculated buck semen has variations in transcription pattern of CLU gene in spermatozoa among bucks and expression levels of CLU transcripts have negative correlation with in vitro sperm characteristics in buck semen samples.
\end{abstract}

Keywords: Clusterin gene, in vitro sperm characteristics, buck semen

A number of seminal plasma proteins have been identified as molecular markers of fertility in different species. Proteins such as osteopontin, prostaglandin D synthase, bovine seminal plasma proteins (BSP A1, A2 and A3), heparin binding proteins (HBPs), fertility associated antigen, phospholipase A2, sperm adhesion Z13, clusterin (CLU) and heat shock proteins(HSPs) have been reported as indicators of fertility (Killian $e t$ al., 1993; Cancel et al.,1999; McCauley et al., 2001 and Moura et al., 2006).

CLU is the one of the fertility associated proteins, which was first isolated from ram rete testis fluid and it showed signs of clustering with rat Sertoli cells and erythrocytes. Hence its name, CLU was derived (Fritz et al., 1983). In the male reproductive tract, it is produced by Sertoli cells and principal epididymal epithelial cells and is translocated to abnormal germ cells and spermatozoa (Sylvester et al., 1984).

CLU is involved in various physiological processes such as it binds and agglutinates abnormal spermatozoa, prevent oxidative damage to the sperm and inhibit complement

How to cite this article: Vengatachalam, M., Loganathasamy, K., Leela, V. and Ramesh, J. (2019). Relationship between clusterin gene expression and in-vitro sperm characteristics in caprine semen. J. Anim. Res., 9(6): 815-820. 
induced sperm lysis in male reproductive tract (Moreno et al., 2002). CLU mainly exists on the surfaces of immature, low motile or morphologically abnormal spermatozoa regardless of whether or not the semen is normal (Carlsson et al., 2004). Abnormal increases and decreases in clusterin are often indicative of poor quality semen (Martinez et al., 2008).

CLU present in the rete testis fluid is synthesized by Sertoli cells and adheres to the surface of testicular spermatozoa. When spermatozoa move through the rete testis and efferent duct, testis-derived CLU is replaced by CLU from the epididymal or seminal vesicle (Griffiths et al., 2009).CLU expression is negatively associated with the percentage of normal sperm morphology (Santos et al., 2014) and high expression of CLU promotes the uptake of stress-damaged proteins by dendritic cells in male reproductive tract (Merlotti et al., 2015).

However, expression of CLU and its relationship with fertility potential of semen have not been fully explored. Hence the present experiment was undertaken to study the transcription pattern of CLU gene and its correlation with in vitro sperm characteristics in buck semen.

\section{MATERIALS AND METHODS}

\section{Plasticware and glassware}

All the plasticware used for the present study viz., centrifuge tubes, microcentrifuge tubes, microtips (different graduations) and PCR tubes were procured from Thermo Scientific, USA. Real time PCR strips and master clear cap strips were procured from Biorad, USA. All the glassware used in this study viz., laboratory bottles, microscopic cover slips $18 \mathrm{~mm} \times 18 \mathrm{~mm}$, microscopic slides, conical flasks and beakers were procured from Borosil, India.

\section{Chemicals}

Chemicals required for PCR, gel electrophoresis and in vitro semen evaluation were procured as detailed below. For real time PCR: RNeasy ${ }^{\circledR}$ mini kit (Qiagen, Germany), high capacity cDNA reverse transcription kit (Thermo Scientific,USA), Taq DNA polymerase 2.0x master mix red (Ampliqon, Denmark), SYBR green I dye (SYBR premix Ex Taq, Takara,Japan), Nuclease free water (Ambion,USA); For gel electrophoresis: Tris acetate gel running buffer (TAE) $(50 \mathrm{X})\left(\right.$ Medox ${ }^{\circledR}$, India), gel loading dye (6X) (Thermo Scientific, USA), gel red nucleic acid stain (Biotium, Canada), agarose (Sigma-Aldrich, USA), DNA marker 100 bp plus ladder (Thermo Scientific, USA), DNA marker 50 bp plus ladder (Thermo Scientific, USA) and For gel extraction: MinElute ${ }^{\circledR}$ Gel Extraction Kit( Qiagen,Germany).

Chemicals required for in vitro evaluation of semen such as eosin stain, nigrosin stain, rose bengal stain, tris buffer, phosphate buffer saline (PBS), thiobarbituric acid and trichloroacetic acid (TBATCA) solution, JC-1 stain (5, 5', 6, 6' - tetrachloro-1, 1', 3, 3'-tetraethylbenzimidazolylcarbocyanine iodide), carboxy fluorescein diacetate (CFDA), propidium iodide (PI), dimethyl sulphoxide (DMSO), giemsa stain, formaldehyde, sodium citrate, sodium pyruvate, sodium chloride, sodium lactate, potassium chloride, calcium chloride, sodium dihydrogen orthophosphate, magnesium chloride, heparin, fatty acid free bovine serum albumin (BSA), gentamicin, and phenol red were procured from Sigma- Aldrich, USA.

\section{Absolute quantification of CLU gene transcripts}

Fresh semen samples were collected from 12 bucks maintained in the organized goat farms by using artificial vagina. The volume of semen immediately after collection was noted and concentration of spermatozoa was assessed by Neubauer's counting chamber from 12 bucks. Normalization of initial concentration of spermatozoa was carried out before proceeding for RNA isolation. So, initial concentration of each sample was made equal. The spermatozoa were isolated from buck semen samples by swim- up protocol using sperm TALP.

Total RNA from the buck spermatozoa were extracted by RNeasy ${ }^{\circledR}$ mini kit (Qiagen, Germany) and first strand cDNA was synthesized from $1 \mu \mathrm{g}$ total RNA by high capacity cDNA reverse transcription kit (Thermo Scientific,USA). Confirmation of CLU gene was performed by conventional PCR with product size $302 \mathrm{bp}$.

The eluted cDNA was sequenced commercially and was subjected to BLAST analysis. Sequencing of the cloned CLU gene from buck semen showed $98 \%$ identity to 
the known caprine sequence (EMBL Accession NO: XM_018052776.1).

The specific size of amplicon 302 bp was observed on 2.0 per cent agarose gel electrophoresis. The concentration of cDNA was $25.9 \mathrm{ng} / \mu$,which contained $7.7 \times 10^{10}$ copies/ $\mu 1$. A series of 10 -fold dilutions starting from $7.7 \times 10^{10}$ to $7.7 \times 10^{1}$ were prepared. The correlation between the cDNA dilution and the threshold cycle $\mathrm{Ct}$ values in real time PCR was analyzed by plotting a standard curve. Quantification of the nucleic acids in the unknown samples was performed by direct comparison with these standards. A linear regression relationship was observed with a coefficient of determination $\left(\mathrm{R}^{2}\right)$ of 0.926 and a slope of -2.238 .

\section{Assessment of in vitro sperm characteristics}

In vitro sperm characteristics such as sperm motility, viability, morphology, plasma membrane integrity, acrosome integrity, DNA integrity and MMP were also assessed from 12 different buck semen samples by standard protocol.

\section{Statistical analysis}

Statistical analysis was carried out by Karl Pearson's coefficient of correlation described by Snedecor and Cochran (1994).

\section{RESULTS AND DISCUSSION}

\section{Expression of CLU gene in buck semen}

Absolute quantification of CLU gene transcripts in 12 buck semen samples was performed. Variation in levels of CLU gene transcripts (2500-22546000 copies) were found among 12 different buck semen samples (Table 1).

This is the first study to document expression levels of CLU gene transcripts from ejaculated buck spermatozoa. But, localization of CLU was demonstrated in previous studies on sperm acrosome, neck and end piece of tail and was associated with late spermatids and spermatozoa by indirect immunofluorescence method (Sylvester et al., 1984). Northern blot analysis showed that two isoforms of CLU (on testicular and epididymal sperm occur due to tissue-specific post-translational modifications (Sylvester et al., 1991). Western blot analysis of sperm membrane extracts from testicular, caput and cauda spermatozoa revealed that testicular CLU was associated with testicular sperm and epididymal CLU was predominantly associated with caput sperm (Mattmueller and Hinton, 1991).

Table 1: Absolute quantification of CLU gene in buck semen samples $(n=12)$

\begin{tabular}{cc}
\hline Buck number & $\begin{array}{c}\text { CLU gene transcripts } \\
\text { (number of copies) }\end{array}$ \\
\hline 1 & 10440 \\
2 & 1732510 \\
3 & 33940 \\
4 & 11377340 \\
5 & 9460 \\
6 & 12900 \\
7 & 22546000 \\
8 & 1235880 \\
9 & 13000 \\
10 & 1277430 \\
11 & 2500 \\
12 & 1084130 \\
\hline
\end{tabular}

Evaluation of in vitro sperm characteristics of buck semen

In vitro sperm characteristics were also studied from 12 buck semen samples. Variation in sperm characteristics such as sperm motility $(60.0-80.0 \%)$, sperm viability (72.0 - 93.0\%), sperm morphology (73.0 - 91.0\%), plasma membrane integrity $(50.0-82.0 \%)$, acrosome integrity $(81.0-93.0 \%)$, DNA integrity $(82.0-93.0 \%)$ and MMP (46.0 - 74.0\%) were found among buck semen samples (Table 2). All the above in vitro sperm characteristics were negatively correlated $(p<0.01)$ with expression levels of CLU gene transcripts (2500-22546000 copies) in spermatozoa isolated from 12 different buck semen samples.

In physiological state, CLU prevents oxidative damage by reactive oxygen species (ROS) attack on the spermatozoa (Moreno et al., 2002). It binds and agglutinates abnormal spermatozoa in bulls (Ibrahim et al., 1999) and act like a chaperone, protecting sperm from the toxic effects 
Table 2: Evaluation of in vitro sperm characteristics of buck semen samples $(n=12)$

\begin{tabular}{|c|c|c|c|c|c|c|c|c|}
\hline \multirow{3}{*}{$\begin{array}{c}\text { Buck } \\
\text { Number }\end{array}$} & \multirow{3}{*}{$\begin{array}{c}\text { Absolute } \\
\text { quantification } \\
\text { of CLU gene }\end{array}$} & \multicolumn{7}{|c|}{ In vitro sperm characteristics } \\
\hline & & \multirow{2}{*}{$\begin{array}{c}\text { Sperm } \\
\text { motility \% }\end{array}$} & $\begin{array}{c}\text { Sperm } \\
\text { livability }\end{array}$ & $\begin{array}{c}\text { Sperm } \\
\text { morphology }\end{array}$ & \multirow{2}{*}{$\begin{array}{c}\text { Sperm plasma } \\
\text { membrane } \\
\text { integrity } \%\end{array}$} & \multirow{2}{*}{$\begin{array}{c}\text { Sperm } \\
\text { acrosome } \\
\text { integrity \% }\end{array}$} & \multirow{2}{*}{$\begin{array}{l}\text { Sperm DNA } \\
\text { integrity } \%\end{array}$} & \multirow{2}{*}{$\begin{array}{l}\text { Sperm } \\
\text { MМР \% }\end{array}$} \\
\hline & & & Live \% & Normal \% & & & & \\
\hline 1 & 10440 & 80 & 87 & 91 & 77 & 90 & 93 & 69 \\
\hline 2 & 1732510 & 70 & 79 & 79 & 60 & 84 & 86 & 53 \\
\hline 3 & 33940 & 80 & 88 & 90 & 67 & 90 & 91 & 63 \\
\hline 4 & 11377340 & 60 & 75 & 77 & 56 & 83 & 85 & 49 \\
\hline 5 & 9460 & 80 & 91 & 90 & 80 & 92 & 91 & 71 \\
\hline 6 & 12900 & 80 & 88 & 90 & 72 & 91 & 90 & 66 \\
\hline 7 & 22546000 & 60 & 72 & 73 & 50 & 81 & 82 & 46 \\
\hline 8 & 1235880 & 70 & 83 & 84 & 62 & 87 & 87 & 57 \\
\hline 9 & 13000 & 80 & 90 & 90 & 70 & 92 & 93 & 65 \\
\hline 10 & 1277430 & 70 & 81 & 82 & 62 & 88 & 87 & 56 \\
\hline 11 & 2500 & 80 & 93 & 90 & 82 & 93 & 91 & 74 \\
\hline 12 & 1084130 & 70 & 84 & 87 & 63 & 89 & 88 & 59 \\
\hline $\begin{array}{c}\text { Coefficient of } \\
\text { correlation }\end{array}$ & & $-0.800 * *$ & $-0.807 * *$ & $-0.827 * *$ & $-0.715^{* *}$ & $-0.805^{* *}$ & $-0.787 * *$ & $-0.736 * *$ \\
\hline
\end{tabular}

of protein precipitation (Humphreys et al., 1999 and Wilson and Smith, 2000). CLU has the ability to inhibit complement-induced sperm lysis (Jenne and Tchopp, 1989) and exerts protective effect on reproductive tract cells including spermatozoa against apoptosis (Bailey et al., 2002) and assists in removal of damaged sperm from epididymis in human beings (Zalata et al., 2012).

Under pathological condition, high level of CLU expression in response to oxidative stress could be the cause for low viability of spermatozoa in buck semen samples and this association probably occurs as a result of ability of CLU to bind damaged portions of hydrophobic regions of sperm membrane (Bailey and Griswold, 1999). Because ROS are highly reactive at pathological levels, they exert significant damage on biomolecules, such as proteins, lipids and nucleic acids (Riffo and Parraga, 1996).

CLU expression was negatively associated with the percentage of normal sperm morphology (Santos et al., 2014). But, positive correlation exists between levels of ROS and percentage of spermatozoa with many kinds of abnormalities like, abnormal heads, acrosome abnormalities, mid piece anomalies, cytoplasmic droplets and tail defects (Sabeti et al., 2016).
The sperm plasma membrane is mostly composed of PUFAs which are susceptible to OS due to the presence of double bond (Agarwal and Seleh, 2002). As LPO cascade proceeds in the sperm, almost $60 \%$ of the fatty acid is lost from the membrane. LPO affects membrane structure and functions such as fluidity, ion gradients, receptor transduction, transport processes and membrane enzymes (Sikka et al., 1995). Peroxides, products of LPO constitute a potential hazard to the structural and functional integrity of spermatozoa (Srivastava et al., 2006).

The acrosome reaction involves fusion of the plasma and outer acrosomal membranes coupled with the release of hydrolytic enzymes allows the sperm to penetrate the zona pellucida and fertilize an oocyte (Abou and Tulsiani, 2000). Induction of premature acrosomal reaction by ROS altered mitochondrial function and reduced the sperm motility.

ROS induced many kinds of DNA damage, including DNA base modifications, chromatin cross linkage and breakage of DNA strand (de Rosa et al., 2003; Evenson and Wixon, 2006). Failure of chromatin decondensation by ROS in OS reduced the viability and fertility of the sperm cells (Cooter et al., 2005 and Wongtawan et al., 2006). ROS can damage DNA and proteins either through oxidation of 
DNA bases (primarily guanine via lipid peroxyl or alkoxyl radicals) or through covalent binding to MDA resulting in strand breaks and cross-linking (Ernster, 1993). ROS can also induce oxidation of critical -SH groups in proteins and DNA, which will alter structure and function of spermatozoa with an increased susceptibility to attack by macrophages (Aitken et al., 1994).

ROS may also adversely affect sperm motility via alterations in mitochondrial function. MMP has been used as a measure of mitochondrial function and is linked to ATP synthesis, import of mitochondrial proteins, calcium homeostasis and metabolite transport (Baumber et al., 2000). ROS stimulates proteins of the BCL-2 family, followed by releasing of mitochondrial cytochrome $\mathrm{C}$ and concomitant activation of caspase 9 and 3 which result in disruption of MMP (Espinoza et al., 2009 and Kothari et al., 2010).

\section{CONCLUSION}

From this experiment, it is evident expression levels of CLU gene have varied among the buck semen samples and expression levels of CLU transcripts have negative correlation with in vitro sperm characteristics.

\section{ACKNOWLEDGEMENTS}

The authors are grateful to Dean, Madras Veterinary College and higher authorities of Tamil Nadu Veterinary and Animal Sciences University for providing necessary facilities and funds to carry out the experiment.

\section{REFERENCES}

Abou, H.A. and Tulsiani, D.R. 2000. Mammalian sperm acrosome: formation, contents, and function. Arch. Biochem. Biophys., 379(2): 173-182.

Agarwal, A. and Saleh, R.A. 2002. Role of oxidants in male infertility: rationale, significance and treatment. Urol. Clin. North Am., 29: 817-824.

Aitken, R.L., West, K.M. and Buckingham, D.W. 1994. Leukocyte infiltration into human ejaculate and its association with sperm quantity, oxidative stress, and sperm function. $J$. Androl., 15: 343-352.

Bailey, R. and Griswold, M.D. 1999. Clusterin in the male reproductive system: localization and possible function. Mol. Cell. Endocrinol., 151: 17-23.
Bailey, R.W., Aronow, B., Harmony, J. and Griswold, M.D. 2002. Heat shock- initiated apoptosis Is accelerated and removal of damaged cells is delayed in the testis of clusterin apo j knockout mice. Biol. Reprod., 66: 1042-1053.

Baumber, J.B., Ball, A., Gravance, C.G., Medina, V., Mina, C.G. and Morel, D. 2000. The effect of reactive oxygen species on equine sperm motility, viability, acrosomal integrity, mitochondrial membrane potential and membrane lipid peroxidation. J. Androl., 21: 895-902.

Cancel, A.M., Chapman D.A and Killian, G.J. 1999. Osteopontin localization in the Holstein bull reproductive tract. Biol. Reprod., 60: 454-460.

Carlsson, L., Ronquist, G. and Nilsson, B.O. 2004. Dominant prostasome immunogens for sperm-agglutinating autoantibodies of infertile men. J. Androl., 25: 699-705.

Cooter, P.Z., Goolsby, H.A. and Prien, S.D. 2005. Preliminary evaluation of a unique freezing technology for bovine spermatozoa cryopreservation. Reprod. Dom. Animal., 40: 98- 99.

de Rosa, M., Zarrilli, S.,Paesano, L., Carbone, U., Boggia, B., Petretta, M., Maisto, A., Cimmino, F., Puca,G., Colao, A. and Lombardi, G. 2003. Traffic pollutants affect fertility in men. Hum. Reprod., 18: 1055-1061.

Ernster, L. 1993. Lipid peroxidation in biological membrane: mechanism and implications. In: Active oxygen, lipid peroxides and antioxidants.Ed: Yagi K, CRC Press, Boca Ranton : 1-38.

Espinoza, J.A., Paasch, U. and Juana, V. 2009. Villegas mitochondrial membrane potential disruption pattern in human sperm. Hum. Reprod., 24: 2079-2085.

Evenson, D. and Wixon, R. 2006. Meta-analysis of sperm DNA fragmentation using the sperm chromatin structure assay. Reprod. Biomed., 12: 466- 472.

Fritz, I.B., Burdzy, K., Setchell, B. and Blaschuk, O. 1983. Ram rete testis fluid contains a protein (clusterin) which influences cell-cell interaction in vitro. Biol. Reprod., 28: 1173-1180.

Griffiths, G.S., Galileo, D.S. and Aravindan, R.G. 2009. Clusterin facilitates exchange of glycosyl phosphatidylinositol-linked SPAM1 between reproductive luminal fluids and mouse and human sperm membranes. Biol. Reprod., 81: 562-570.

Humphreys, D.T., Carver, J.A., Smith, S.B.E. and Wilson, M.R. 1999. Clusterin ha chaperone- like activity similar to that of small heat shock proteins. J. Biol. Chem., 274: 6875-81.

Ibrahim, N.M., Troedsson, M.H., Foster, D.N., Loseth, K.J., Farris, J.A., Blaschuk, O. and Crabo, B.G. 1999. Reproductive tract secretions and bull spermatozoa contain different clusterin isoforms that cluster cells and inhibit complement induced cytolysis. J. Androl., 20: 230-240. 
Killian, G.J., Chapman, D.A. and Rogowski, L.A. 1993. Fertility associated proteins in Holstein bull seminal plasma. Biol. Reprod., 49: 1202-1207.

Kothari, S., Thompson, A., Agarwal, A. and Plessis, S.S. 2010. Free radicals: their beneficial and detrimental effects on sperm function. Indian J. Exp. Biol., 48: 425-435.

Martinez, H.J., Mateo, S. and Vidal-Taboada, J.M. 2008. Identification of proteomic differences in asthenozoospermic sperm samples. Hum. Reprod., 23: 783-791.

Mattmueller, D.R. and Hinton, B.T. 1991. In vivo secretion and association of clusterin (SGP-2) in luminal fluid with spermatozoa in the rat testis and epididymis. Mol. Reprod. Dev., 30(1): 62-69.

McCauley, T.C., Zhang, H., Bellin, M.E. and Ax, R.L. 2001. Identification of a heparin-binding protein in bovine seminal fluid as tissue inhibitor of metalloproteinases 2. Mol. Reprod. Dev., 58: 336-341.

Merlotti, A., Dantas, E., Lenicov, F.R., Ceballos, A., Jancic, C., Varese, A., Rubione, J., Stover, S., Geffner, J. and Sabatte, J. 2015. Fucosylated clusterin in semen promotes the uptake of stress- damaged proteins by dendritic cells via DC-SIGN. Hum. Reprod., 30(7): 1545-1556.

Moreno, R.C., Boilard, M., Sullivan, R. and Sirard, M.A. 2002. Characterization of secretory proteins from cultured cauda epididymal cells that significantly sustain bovine sperm motility in vitro. Mol. Reprod. Dev., 63: 500-509.

Moura, A.A., Chapman, D.A., Koc, H. and Killian, G.J. 2006. Proteins of the cauda epididymal fluid associated with fertility of mature dairy bulls. J. Androl., 27: 534-541.

Riffo, M.S. and Parraga, M. 1996. Study of the acrosome reaction and the fertilizing ability of hamster epididymalcauda spermatozoa treated with antibodies against phospholipase A2 and/or lysophosphatidylcholine. J. Exp. Zool., 27(5): 459-467.

Sabeti, P., Pourmasumi, S., Rahiminia, T., Akyash, F. and Talbei, A.R. 2016. Etiologies of sperm oxidative stress. Intl. J. Reprod. Bio. Med., 4: 231-240.
Santos, E.A.A., Sousa, P.C., Martins, J.A.M., Moreira, R.A., Moreira, A.C.O.M., Moreno, F.B.M.B., Oliveira, M.F., Moura A.A. and Silva, A.R. 2014. Protein profile of the seminal plasma of collared peccaries. Reproduction, 147: 753-764.

Sikka, S.C., Rajasekaran, M. and Hellstrom, W.J. 1995. Role of oxidative stress and antioxidants in male infertility. $J$. Androl., 16: 464-471.

Snedecor, G.W. and Cochran, W.G. 1994. Statistical Methods. The Iowa State Univ. Press, USA.

Srivastava, S., Desai, P. Coutinho, E. and Govil, G. 2006. Mechanism of action of Larginine on vitality of spermatozoa is primarily through increased biosynthesis of nitric oxide. Biol. Reprod., 74: 954-958.

Sylvester, S.R., Morales, C., Oko, R. and Griswold, M.D. 1991. Localization of sulfated glycoprotein-2 (clusterin) on spermatozoa and in the reproductive tract of the male rat. Biol. Reprod., 45(1): 195-207.

Sylvester, S.R., Skinner, M.K. and Griswold, M.D. 1984. A sulfated glycoprotein synthesized by Sertoli cells and by epididymal cells is a component of the sperm membrane. Biol. Reprod., 31(5): 1087-1101.

Wilson, M. and Smith, E. 2000. Clusterin is a secreted mammalian chaperone. Trends Biochem. Sci., 25: 95-98.

Wongtawan, T., Saravia, F., Wallgren, M., Caballero, I. and Rodriguez-Martinez, H. 2006. Fertility after deep intrauterine artificial insemination of concentrated low-volume boar semen doses. Theriogenology, 65: 773-787.

Wyatt, A.R., Yerbury, J.J., Ecroyd, J.J. and Wilson, M.R. 2013. Extracellular chaperone and proteostasis. Annu. Rev. Biochem., 82: 295-322.

Zalata, A., Samonoudy, E.J.A.Z., Shaalan, D., Baiomy, Y.E.L., Taymour, M. and Mostafa, T. 2012. Seminal clusterin gene expression associated with seminal variables in fertile and infertile men. J. Urol., 188: 1260-1264. 